\title{
Simulation of the Operation of a Single Pixel Camera with Compressive Sensing in the Long-Wave Infrared
}

\section{Anna Szajewska}

The Main School of Fire Service, 52/54 Słowackiego St., 01-629 Warsaw, Poland

\begin{abstract}
Imaging with the use of a single pixel camera and based on compressed sensing (CS) is a new and promising technology. The use of CS allows reconstruction of images in various spectrum ranges depending on the spectrum sensibility of the used detector. During the study image reconstruction was performed in the LWIR range based on a thermogram from a simulated single pixel camera. For needs of reconstruction CS was used. A case analysis showed that the CS method may be used for construction of infrared-based observation single pixel cameras. This solution may also be applied in measuring cameras. Yet the execution of a measurement of radiation temperature requires calibration of results obtained by CS reconstruction. In the study a calibration method of the infrared observation camera was proposed and studies were carried out of the impact exerted by the number of measurements made on the quality of reconstruction. Reconstructed thermograms were compared with reference images of infrared radiation. It has been ascertained that the reduction of the reconstruction error is not directly in proportion to the number of collected samples being collected. Based on a review of individual cases it has been ascertained that apart from the number of collected samples, an important factor that affects the reconstruction fidelity is the structure of the image as such. It has been proven that estimation of the error for reconstructed thermograms may not be based solely on the quantity of executed measurements.
\end{abstract}

Keywords: single pixel camera, compressed sensing, infrared measurements, thermal camera

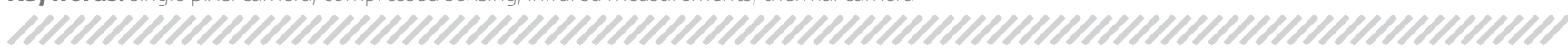

\section{Introduction}

Presently in infrared thermography use is primarily made of two ranges of electromagnetic radiation: LWIR (Long-Wave InfraRed) 8-12 $\mathrm{mm}$ and MWIR (Medium-Wave Infrared) $3-5 \mu \mathrm{m}$. The LWIR band is frequently used because the radiation strength of objects with a temperature close to $300 \mathrm{~K}$ is higher than for the MWIR range, which is a direct effect of the shape of the Planck's curves for a black body [1]. The currently used detectors for imaging infrared are mainly FPA (Focal Plane Array) bolometric matrices. On the other hand, popular CMOS cameras are only suitable for observations of the SWIR (Short-Wave InfraRed) 1.4-3um range. There are still fields in which the utilisation of FPA is literally impossi-

Autor korespondujący:

Anna Szajewska, aszajewska@sgsp.edu.pl

Artykuł recenzowany

nadesłany 31.05.2021 r., przyjęty do druku 28.06.2021 r. ble. These include measurements of spectral ranges that are beyond possibilities offered by the present matrices, given the insignificant radiated power or frequency of the electromagnetic wave lying beyond the detection spectrum. In such rare applications it is necessary to use expensive and bulky photomultipliers or avalanche diodes. Equally cumbersome are spectrophotometric measurements [2,3] and measurements of millimetre waves. Among other non-matrix solutions an old concept of a single pixel camera SPC (Single-Pixel Camera) has been developed, the sources of which may be sought in the Nipkov disc [4]. A new method was developed of image reconstruction using compressed sensing by a single detector. Based on methods developed by Candes, Rondberg and Tao [5] recently a mathematical approach has been developed to the construction of a single pixel camera, which similarly as in the initial solution makes use of a single detector only, but the data sampling method differs $[6,7]$. One of the first trials has been carried out by a team of researchers from the University of Rice in 2006 [8]. According to the authors the new operating principle would allow imaging based on spectral ranges, which for the meantime are unavailable for FPA (e.g. terahertz frequencies) $[2,9,10]$. The first attempt at building an observation camera in LWIR has already been undertaken [11]. However, there is no available information as 
to the existing measuring SPC camera that would make use of CS for far infrared. There is still a theoretical problem for the development of such a camera, and namely the necessity of identifying the measurement uncertainty and the technical concern is the structure of camera modulator.

\subsection{Single pixel camera with compressed sensing}

Studies of infrared images in the band of 8-12 $\mu \mathrm{m}$ are cumbersome for technological reasons. Taking into account technological limitations, the first image infrared recorders were based on a single SPD (single pixel detector) [12]. Each pixel of the image was scanned with the use of a mobile optical system. A significant drawback of this solution was the long scanning time of the entire image, which as an effect contributed to the development of microbolometric matrices with dimensions that enable quick imaging at a high resolution. Despite a troublesome structure, a significant advantage of the SPD measurement system is the homogenous nature of measurement sensitivity. The measurement of the entire image by a single detector is deprived of non-linearity connected with the sensitivity of particular FPA elements. Pixels in microbolometric matrices have a differing sensitivity, which should be compensated by the software. In matrix cameras the amount of energy supplied to the matrix pixel comes from a section of the projected image. The same principle applies to older SPC scanning cameras. Image acquisition in SPC that makes use of CS consists of sequential observations of numerous pixels at the same time. This means that the amount of radiation reaching the detector in a single measurement is equal to the amount of energy coming from a set of selected pixels-hence the sensitivity of the detector may be lower than in FPA, and this in turn increases the relation of the signal to the detector's thermal noise. In normal circumstances reconstruction of an image requires a number of measurements conforming to the number of all pixels on the assumption that each measurement concerns the subsequent pixel. The CS reconstruction method [5, $13,14]$ enables a programme-based image reconstruction based on a much lower number of samples than the number of all pixels in the image. It is clear that in the case of this method a part of some insignificant information may be lost, similarly as in loss methods of image compression. In traditional cameras acquisition takes place spatially in one moment (limited only by the detector's exposure time). In a single pixel camera image acquisition takes place by spatial and time multiplexing. This implies a longer time needed to obtain samples, which is an obvious drawback of this method. Furthermore, research is being carried out on movement recording [15]. Correct image reconstruction requires the selection of pixel sequence for each measurement (measurement matrix). This may be done with the use of a SLM modulator (spatial light modulator) provided between the detector and the source of radiation. SLM may function on a transmission or reflection principle. To enhance the effectiveness (shorten the time) studies are underway on adaptive algorithms that generate pixel masks, which may considerably minimise the number of required measurements [16-18]. A solution that still remains universal is the initial concept of applying mask sets, which meet the property of RIP (Restricted Isometry Property). This particular property is usually fulfilled by masks generated in a random way [19]. Adaptive algorithms of mask selection prove to be more effective in specified cases, as has been indicated in [20]. An interesting structural property of SPC with CS is the fact that retuning of the camera to a different spectral range is theoretically limited to a change of the type of used detector. The second property is the possibility of eliminating the optical system [21]. A change of the focal length may only be limited to a change of distance between the detector and the modulator, similarly as in the camera obscura. This simplifies the structure and eliminates the problem of diverse kinds of optical aberrations. Presently studies are underway on observation cameras in the medium infrared belt and hyperspectral cameras [2, 9, 22].

\subsection{Image acquisition}

Experiments on the development of CS carried out to date were based on two SLM solutions. The first one of them is image projection on a matrix of mobile mirrors. Given the availability of the DMD (Digital Micro-mirror Device) technology, such a solution is frequently used in research [3, 6-9,14]. Matrices of movable mirrors are executed in the MEMS (Micro-electro-mechanical systems) technology. The dimensions of DMD micro mirrors are equal to a few or several micrometres and are made of aluminium. Mirrors are set up in matrices that allow imaging in resolutions ranging from VGA to 4k Ultra HD. Mass-produced matrices allow mirror revolution by an angle of $\pm 12^{\circ}$ or $\pm 17^{\circ}$ [23]. Regardless of the type, they may operate at different spectrum ranges: $363-420 \mathrm{~nm}, 400-700 \mathrm{~nm}$, 700-2500 nm. Maximum frequencies of mirror position change may come up to $32 \mathrm{kHz}$ for the whole matrix. The usage of those matrices in SPC is an issue of secondary importance. However, the application of the DMD technology for SPC still remains in an experimental phase. There are presently certain limitations of this technology related to its use in far infrared: - the mirror may not be smaller than the length of the wave, and hence the length of the tested wave is limited by the size of the micro-mirror,

- there is a transmittance barrier of masking glass for the DMD matrix for waves of 8-12 $\mu \mathrm{m}$,

- the sampling time is limited by the mechanical inertness of the micro-mirror DMD, i.e. the bigger the length of the wave, the larger and slower is the mirror,

- the emissivity coefficient of aluminium used to make micro-mirrors also depends on the reflection angle of infrared radiation from the mirror surface (this effect does not occur for visible light) [1] .

The structure of a functional SLM for LWIR is feasible, yet it poses a technical problem. Due to the applied type of masking glass, it is impossible for any DMD matrices to be applied for far infrared dimensions, because to date there is no available information on the development of a DMD matrix for the range of 8-12 $\mu \mathrm{m}$.

The second solution is projecting the image directly on a detector shielded by perforated masks $[2,24]$. For visible light a modulator has been made of a LCD matrix [21] yet due to the material such a solution may not be applied for far infrared. Hong-Chao Liu et al. [11] have executed reconstructions of image $51 \times 51$ pixels applying as SLM paper perforated diaphragm with dimensions of $145.35 \mathrm{~mm} \times 145.35 \mathrm{~mm}$ having the radiation transmittance factor of $99 \%$.

Figure 1 presents the operational concept of the camera with the image shielded by masks of selected pixels. Each time the mask is changed, the total amount of radiation reaching the photodetector should be recorded. The sequence of shielding pixels by masks is a physical reflection of the mathematical measurement matrix. After execution of measurements for the whole sequence - the acquisition process is completed. Data collection is limited to selective distribution of radiation from selected pixels and saving the recorded amount of radiation reaching the detector. This is an important advantage in the event of devices with modest computational capacities, because image acquisition as such does not require a high computational capacity, but merely saving the result sequence.

The scientific aim of the research was to review possibilities of applying SPC with CS for reconstruction of images in far infrared for observation and measurement purposes. Research conducted in diverse research centres $[15,19,20]$ is focused on 


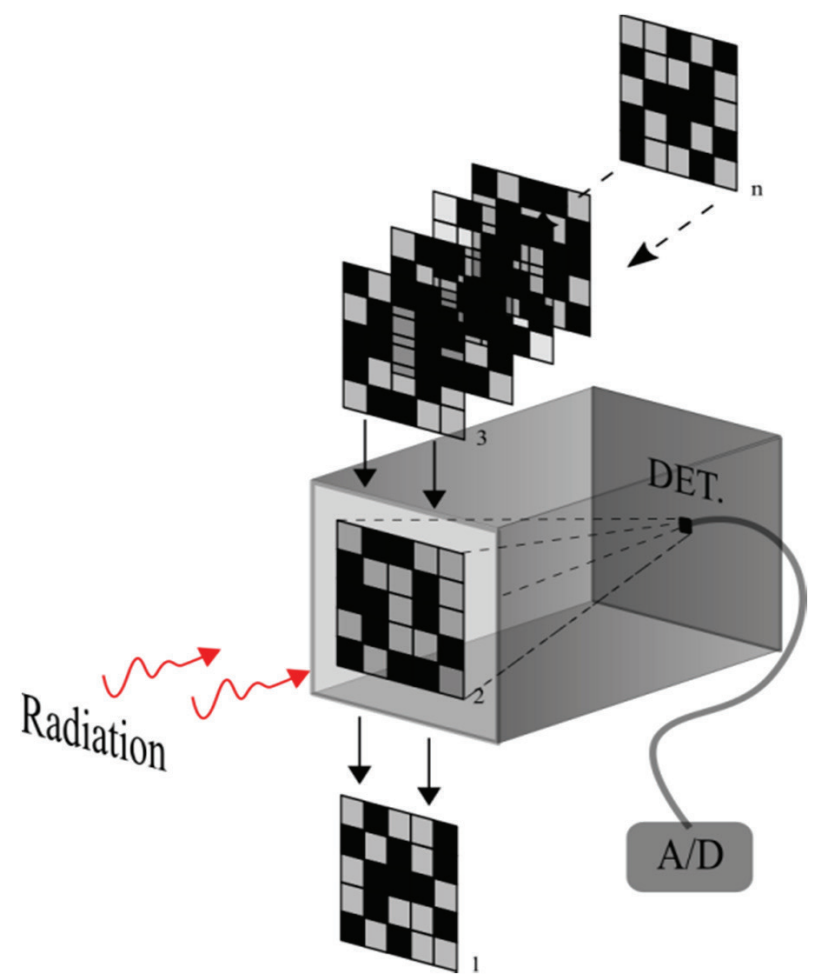

Fig. 1. Rule of operation of a single pixel camera

Rys. 1. Zasada działania kamery jednopikselowej

optimising algorithms to achieve better image reconstruction. Given structural difficulties of the modulator, there are no known data available yet as to the development of an infrared measurement camera for the range of 8-12 $\mu \mathrm{m}$. Owing to the emissivity coefficient that depends on the material, measurement in LWIR has different specific features than observations in visible light. The research was not focused on the algorithm efficiency and the selection of masks, but instead particular attention was paid to the possibility of applying this solution for observations and measurements in LWIR. In the undertaken study a standard image reconstruction algorithm was used (recovery of sparse signals via convex programming), and furthermore possibilities and limitations have been indicated for the application of this technique.

\section{Materials and Methods}

It was assumed that there was no need of using a physical SPC for needs of research on image reconstruction. In the present study the image acquisition stage was simulated in the MATLAB programme based on actual thermograms obtained from a matrix camera. The initial infrared image has been sampled using a common Flir ThermaCAM SC640 measurement camera working in infrared and then it was mathematically processed into a signal similar as would have been obtained from SPC.

Considering that the number of measurements in CS is lower than the number of all pixels in the image, the problem of reconstruction is limited to solving an imprecise set of linear equations. Authors of the method [5] have established that for actual images that prevail in nature there are images, the signal components of which are rare. Consequently the authors have presented two conditions for the image to be reconstructed. The sampled signal has to have a rare nature of data occurrence or at least one should be compressible. This means that from among values that occur in a signal many should have insignificant values as compared to a lower amount of data with considerably higher values. The second condition is the in coherent measurement process [5]. This condition may be fulfilled thanks to appropriate selection of the matrix in a random way [20]. The concept of compressed sensing is based on a smaller number of measurements $m$ than the size of signal $n$ (number of all pixels). The number of significant components of signals is lower than the number of measurements.

$$
s<m<<n
$$

where: $s$ - the number of significant components of signal, $m$ - minimum number of measurements, $n$ - the number of all components in the signal.

Each measurement consists in determination of the signal strength $f$ based on components of signal baseand components of signal $x_{i}$

$$
f=\sum_{i=1}^{n} x_{i} \psi_{i}
$$

where: $f$ - signal, $\Psi_{\mathrm{i}}-$ components signal base, $x_{i}-$ components signal

The vague equation of the entire measurement sequence acquires the following matrix form:

$$
y=\Phi f=\Phi \Psi x=A x
$$

where: $y$-measurement vector $(m \times 1)$ is the matrix of measurement results. In this case, it is a series of measurements of the radiation incident on the detector partially obscured by a modulator sequentially controlled by rows of the sampling matrix $\Phi, \Psi$ - signal base $A$ - measuring matrix, $x$ - studied image in the matrix form $(n \times 1)$. The Fig. 2 shows the CS method, where in $\mathrm{X}$ is located s-non zero values.

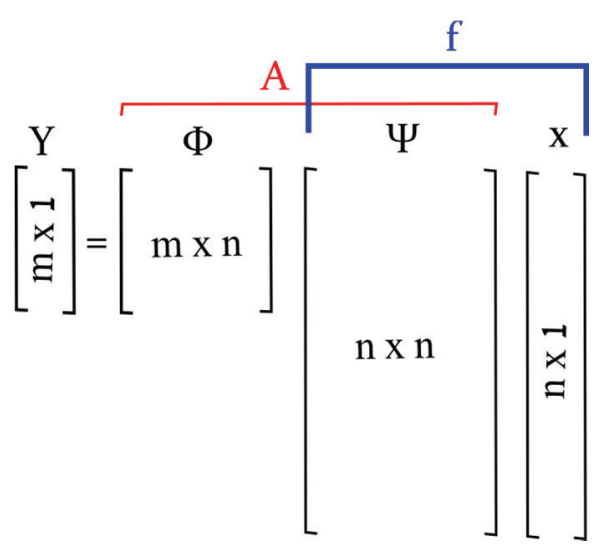

Fig. 2. The concept of CS matrix calculus

Rys. 2. Koncepcja rachunku macierzowego CS

It was assumed that the studied signal has the nature of rare occurrence. From among an infinite number of solutions for a vague set of equations as a rule a solution is to be selected, for which the total of all unknown equations is the lowest. With this in mind use is made of minimisations of norm $\ell_{1}$.

$$
\min _{x}\|x\|_{\ell_{1}} \quad \text { subiect to } A x=y
$$

A solution of this problem is constituted by optimising linear programming with polynomial complexity. Both to generate the measurement vector, measurement matrix and for needs of reconstruction use was made of a packet of $\ell_{1}$ - Magic in the MATLAB environment [25]. Figure 3 presents a concept of the experiment. 


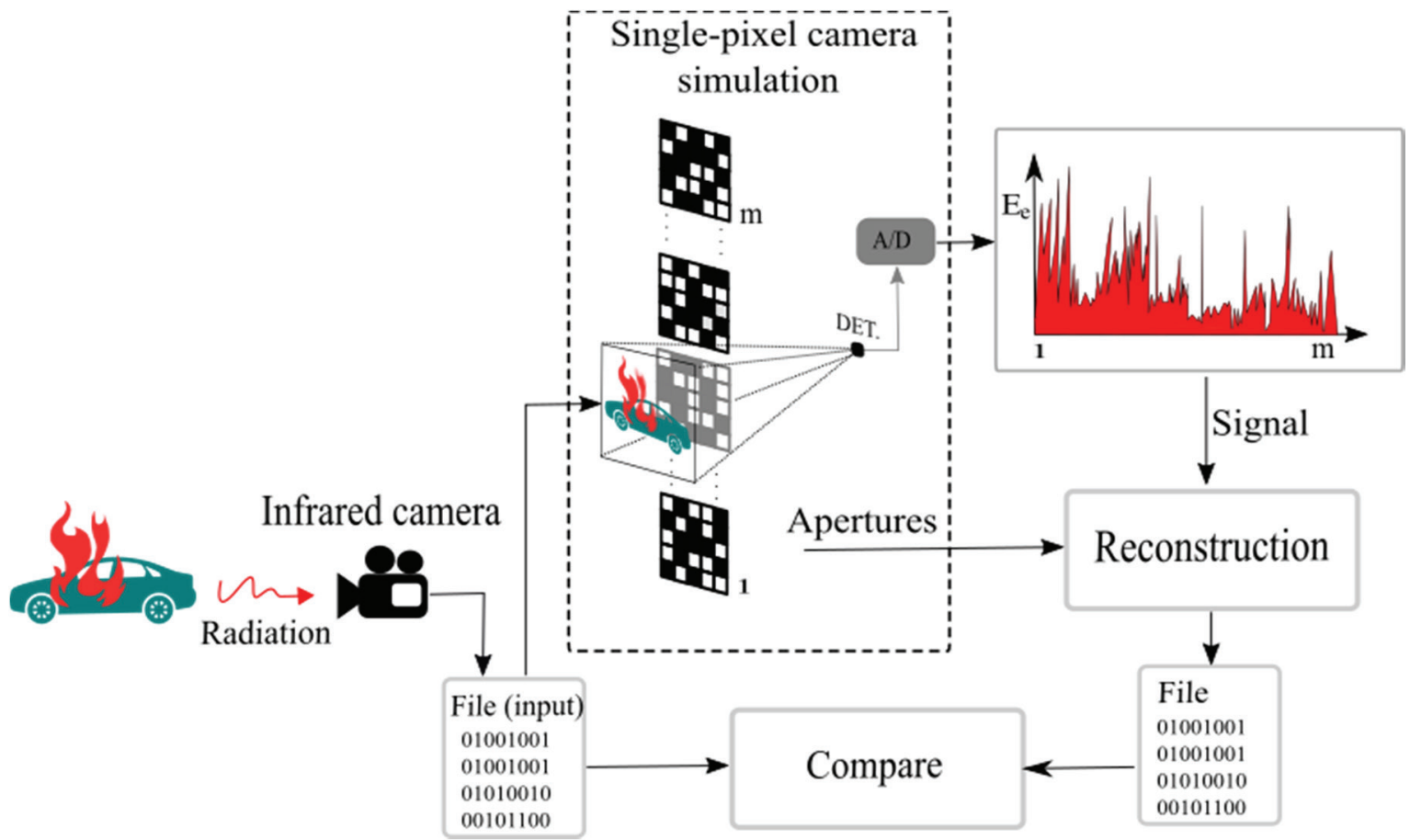

Fig. 3. Conceptual diagram of the experiment

Rys. 3. Schemat koncepcyjny eksperymentu

The analysed thermogram came from a measuring camera. Setting out of the temperature of the analysed object in microbolometric matrix measuring cameras is only feasible once the emissivity coefficient has been determined. If the emissivity coefficient $\varepsilon$ is unknown, the thermogram does not present temperature distribution, but merely radiation distribution. For needs of the assimilated measurement use has been made of this type of distribution for $\varepsilon=1$. The determination of actual temperature was left as a secondary action, similarly as in standard matrix measurements. During a simulated measurement the output value for a single measurement constituted a total of values of all unmasked pixels pursuant to formula 2 . The entire assimilated measurement consisted of generating two matrices:

- matrix of results $[\mathrm{m} \times 1]$ (matrix of actual figures),

- matrix of measurement matrices $[\mathrm{m} \times \mathrm{n}]$ (zero-one matrix), where: $m$ - number of measurements, $n$ - number of pixels in image.

The matrix of measurement matrices was generated in a random way independently for each measurement. The reconstructed image was then compared with the input thermogram.

Before reconstruction of the image, the result matrix was subjected to standardisation. To allow the reconstruction of actual radiation values total radiation was measured (all pixels unmasked) which was then used to set out the mean value for the whole thermogram. Figure 4 presents a diagram that illustrates the process of temperature measurement.

Calibration was achieved by multiplying the reconstructed image by the mean value. The result is a distribution of the recorded infrared radiation. The value of total radiated power $f$ was obtained by adding to the measurement sequence of the complementary aperture for another random aperture $f_{x}$, coming from the measurement matrix, formula 5 .

$$
f=f_{x}+f_{\bar{x}}
$$

A synthesis of results from the selected and negated mask constitutes the total radiation of the image. Setting out of radiation temperature based on emissivity of the observed object is a general problem applicable to all types of cameras and was not covered by the subject of research. Consequently

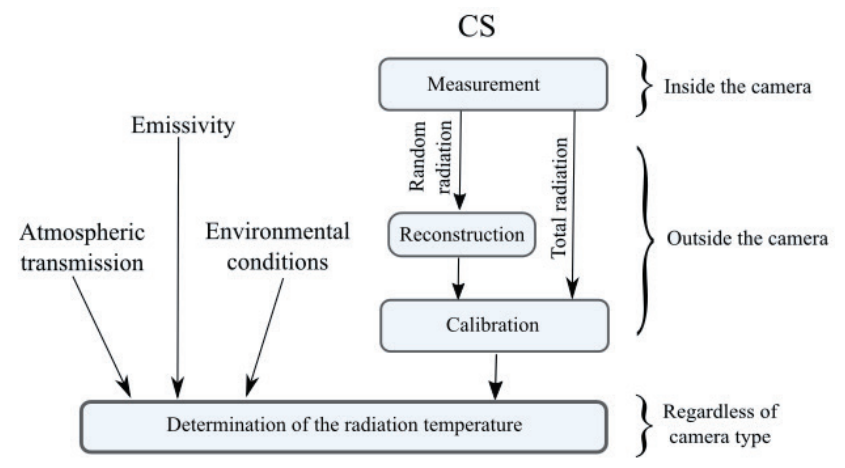

Fig. 4. Diagram of measurement executed with a SPC camera with CS Rys. 4. Schemat wykonania pomiaru kamerą SPC z CS

in the further part a comparison was carried out of radiation values of the reconstructed thermograms and not temperatures.

\section{Results and Discussion}

The analysis was carried out on the basis of three reference images (Fig. 5). Thermogram 1 is an image of a copper plate, onto which two types of lacquer had been powder sprayed having different emissivity coefficients. The plate was next heated with a burner. Thermogram 2 is a view of forest undergrowth heated up by solar radiation, while thermogram 3 is an infrared view of a burning car. The measurement range was $0-550{ }^{\circ} \mathrm{C}$. Three analysed thermograms have a different structure, temperature scope $\left[{ }^{\circ} \mathrm{C}\right], \mathrm{CV}$ (Coefficient of Variation), standard deviation $\sigma$ as well as the percentage of pixels that constitute edges delineated using the Canny filter.

Table 1 presents parameters of reference images after their standardisation (standardisation causes all dimensions for which the distance is counted with the same significance).

Thermograms in Figures 5, 7 have to be reconstructed at the resolution of $256 \times 256$ pixels. Reduced resolution affects the lower computational cost. For the SPD scanning this would require 65536 measurements. If CS is applied, 656 measurements were assimilated in the shortest sequence, which comes 
(a)

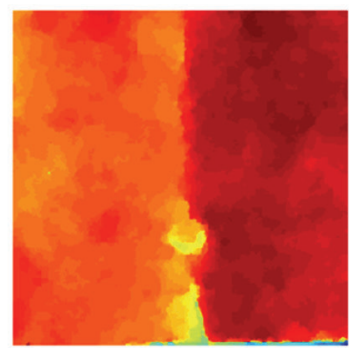

Reconstruction 1\%

(d)

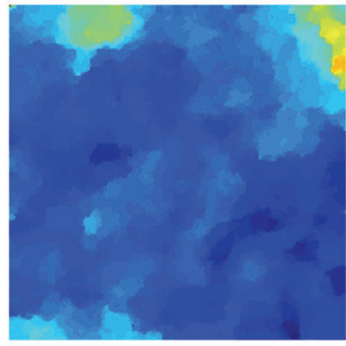

Reconstruction $1 \%$

(g)

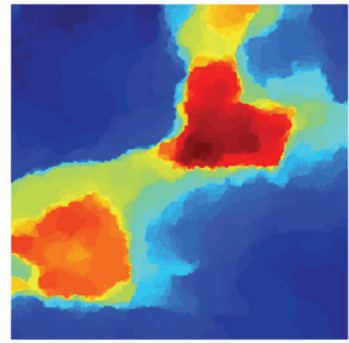

Reconstruction 1\% (b)

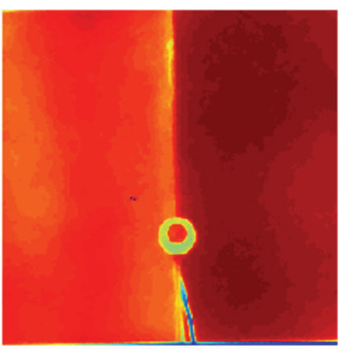

Reconstruction $10 \%$

(e)

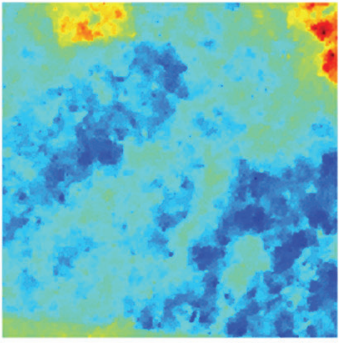

Reconstruction $10 \%$

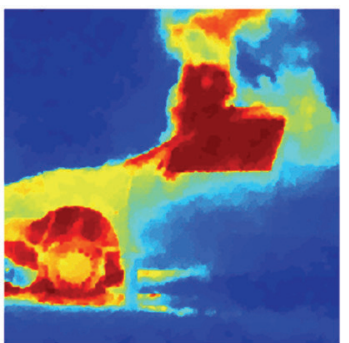

Reconstruction $10 \%$ (c)
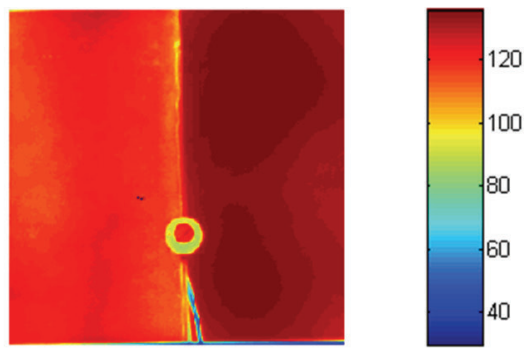

Thermogram 1
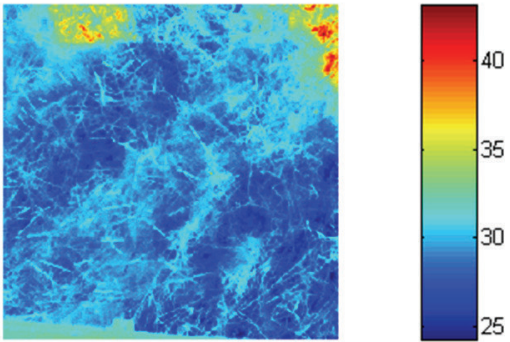

Thermogram 2
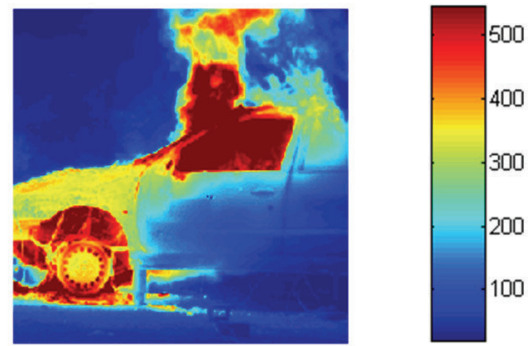

Thermogram 3

Fig. 5. Result of reconstruction of a thermogram ( $256 \times 256$ pixels) on the Celsius scale for different values obtained by algorithm $\ell_{1}-$ Magic in the MATLAB environment. (a) Thermogram 1 with the use of 656 samples, (b) Thermogram 1 with the use of 6556 samples, (c) Thermogram 1 of reference image, (d) Thermogram 2 with the use of 656 samples, (e) Thermogram 2 with the use of 6556 samples, (f) Thermogram 2 of reference image, (g) Thermogram 3 with the use of 656 samples, (h) Thermogram 3 with the use of 6556 samples, (i) Thermogram 3 of reference image Rys. 5. Wynik rekonstrukcji termogramu (256 × 256 pikseli) w skali Celsjusza dla różnych ilości pobranych wartości algorytmem $\ell_{1}-$ Magic w środowisku MATLAB. (a) Termogram 1 przy użyciu 656 próbek, (b) Termogram 1 przy użyciu 6556 próbek, (c) Termogram 1 obrazu referencyjnego, (d) Termogram 2 przy użyciu 656 próbek, (e) Termogram 2 przy użyciu 6556 próbek, (f) Termogram 2 obrazu referencyjnego, (g) Termogram 3 przy użyciu 656 próbek, (h) Termogram 3 przy użyciu 6556 próbek, (i) Termogram 3 obrazu referencyjnego

Table 1. Characteristics of standardised thermograms

Tabela 1. Charakterystyka termogramów poddanych standaryzacji

\begin{tabular}{|c|c|c|c|}
\hline n.o. & $\sigma$ & CV & edge share [\%] \\
\hline Thermogram 1 & $1.2861 \cdot 10^{-6}$ & 21.4 & 1.7425 \\
\hline Thermogram 2 & $1.0121 \cdot 10^{-6}$ & 16.8 & 16.8212 \\
\hline Thermogram 3 & $1.4020 \cdot 10^{-5}$ & 171.8 & 6.2179 \\
\hline
\end{tabular}

up to approximately $1 \%$ as compared to scanning of all pixels. During the execution of measurement thermograms the main focus of interest was measuring radiation at the given point. Studies comprised the difference in radiation reconstruction in relation to the reference thermogram in the function of the number of samples. Figure 6a presents the dependence between the ratio of the number of samples and Pearson's linear correlation $r_{a, b}$ of reference image vectors $\mathrm{f}(\mathrm{a})$ and the vector of a reconstructed image $f(b)$. The correlation was set out based on formula 6 .

$$
f=f_{x}+f_{\bar{x}}
$$

Figure $6 \mathrm{~b}$ presents the ratio of peak signal to noise PSNR expressed by formula 7 .

$$
P S N R=10 \log _{10}\left(\frac{M A X^{2}}{M S E}\right)
$$

MAX is the measurement resolution of the camera, MSE is the mean square error between the reference thermograms and reconstruction.

An increase of the number of samples leads to a non-linear improvement of the correlation ratio and enhancement of PSNR. Yet the enhancement rate differs for the three cases, and also depends on the image structure. Larger ranges of measured temperatures lead to an impairment of PSNR and better shape mapping.

Shape mapping is of importance in observation cameras. Figure 7 presents a temperature distribution with the use of isotherm, which reflect the accuracy of shape reconstruction. Those are isotherm for $1 \%$ and $10 \%$ of the maximum number of samples and reference images. Based on the low number of measurements it is possible to observe contours and the correct situation of the warmest and coolest points. At the level of $10 \%$ the major part of image details may be observed.

The temperature gradient between isotherm for thermogram 1 and 2 equalled to $1{ }^{\circ} \mathrm{C}$ and $10{ }^{\circ} \mathrm{C}$ for thermogram 3 . A problem in the usage of CS is selecting the minimum number of measurements to reflect the original thermogram. Researchers Candes and Wakin [26] have proven that the minimum number of measurements $m$ needs to fulfil the condition presented by formula 8 .

$$
m \geq C \cdot \mu^{2}(\phi, \psi) \cdot s \cdot \log (n)
$$


(a)

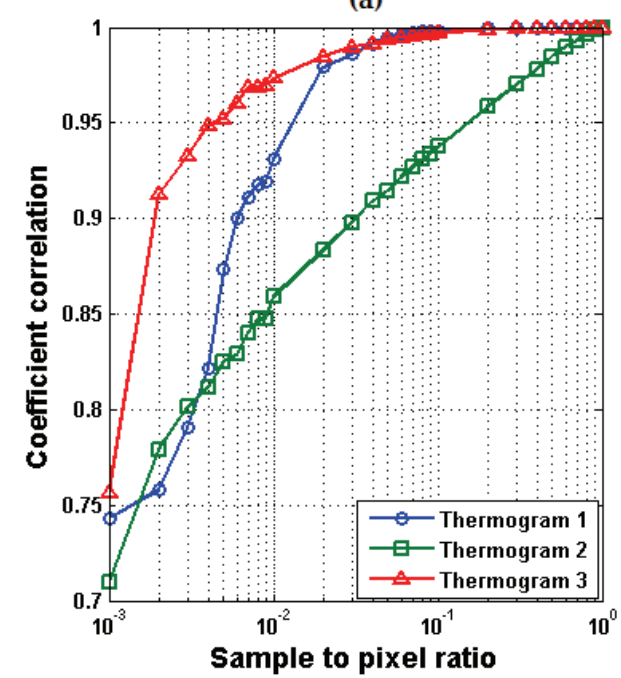

(b)

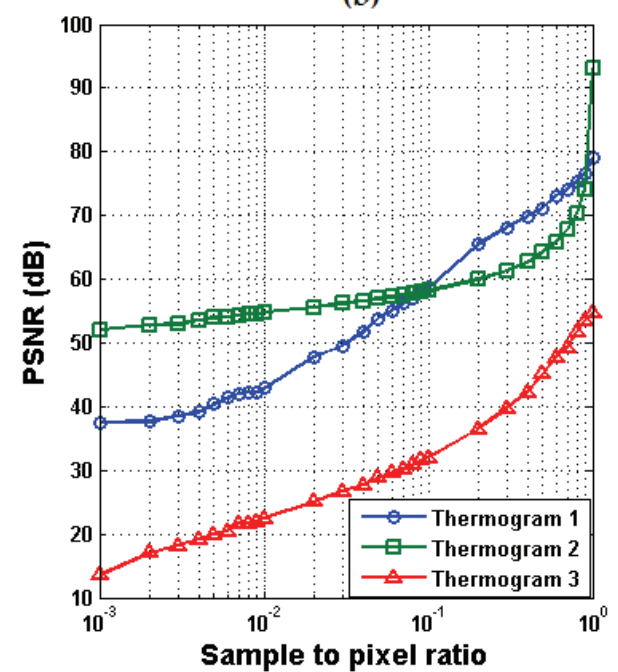

Fig. 6. Comparison of reconstruction to the reference image for three cases. (a) Dependence of correlation between the ratio of the number of obtained samples to all pixels in the image. (b) Dependence of PSNR of the ratio of obtained samples to all pixels in the image

Rys. 6. Porównanie rekonstrukcji do obrazu odniesienia dla trzech przypadków. (a) Zależność korelacji od stosunku liczby pobranych próbek do wszystkich pikseli w obrazie. (b) Zależność PSNR od stosunku liczby pobranych próbek do wszystkich pikseli w obrazie

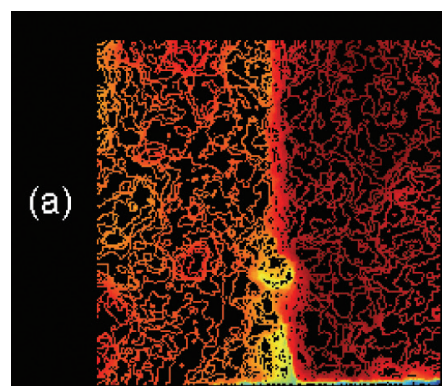

Reconstruction $1 \%$

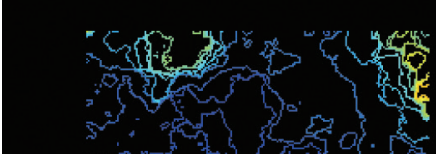

(d)

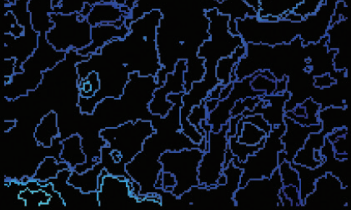

Reconstruction $1 \%$

(g)

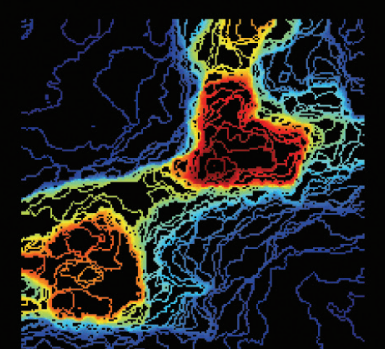

Reconstruction $1 \%$ (b)

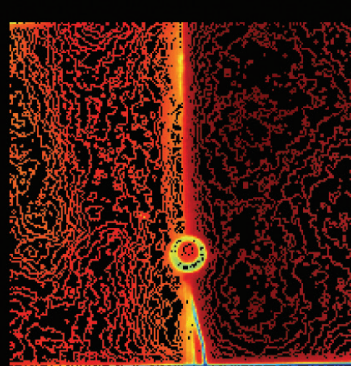

\section{Reconstruction $10 \%$}

(e)

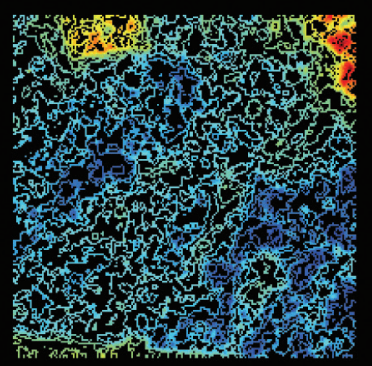

Reconstruction $10 \%$

(h)

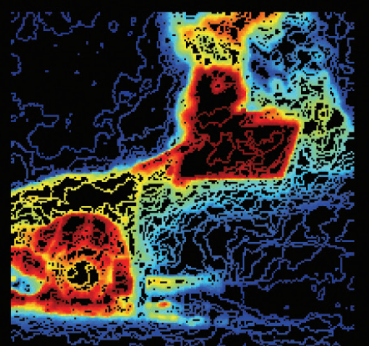

Reconstruction $10 \%$ (c)

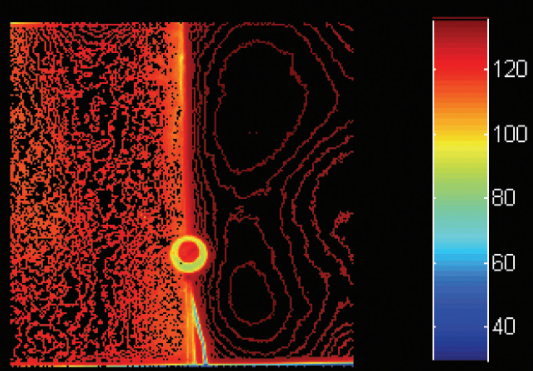

Thermogram 1

(f)
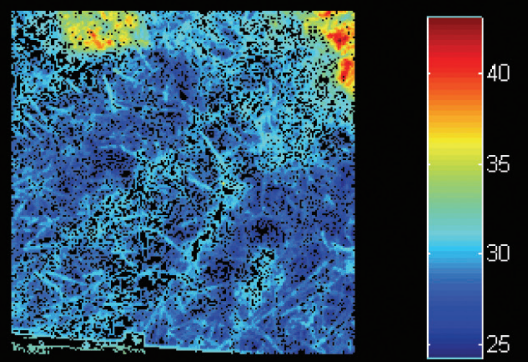

Thermogram 2

(i)

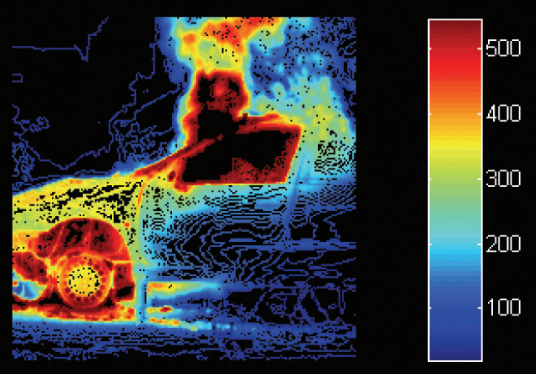

Thermogram 3

Fig. 7. Shape mapping by temperature gradient $\left[{ }^{\circ} \mathrm{C}\right]$ for different numbers of samples in relation to the reference thermogram. (a) Reconstruction from 656 samples, spacing of isotherm $1{ }^{\circ} \mathrm{C}$, (b) Reconstruction from 6556 samples spacing of isotherm $1{ }^{\circ} \mathrm{C}$, (c) Reference thermogram 1,spacing of isotherm $1^{\circ} \mathrm{C}$, (d) Reconstruction from 656 samples spacing of isotherm $1^{\circ} \mathrm{C}$, (e) Reconstruction from 6556 samples spacing of isotherm $1{ }^{\circ} \mathrm{C}$, (f) Reference thermogram 2, spacing of isotherm $1{ }^{\circ} \mathrm{C}$, (g) Reconstruction from 656 samplesspacing of isotherm $10^{\circ} \mathrm{C}$, (h) Reconstruction from 6556 samples, spacing of isotherm $10^{\circ} \mathrm{C}$, (i) Reference thermogram 3 , spacing of isotherm $10^{\circ} \mathrm{C}$

Rys. 7. Odwzorowanie kształtu gradientem temperatury $\left[{ }^{\circ} \mathrm{C}\right]$ dla różnych ilości próbek względem termogramu referencyjnego. (a) Rekonstrukcja z 656 próbek odstęp izoterm $1{ }^{\circ} \mathrm{C}$, (b) Rekonstrukcja z 6556 próbek odstẹp izoterm $1{ }^{\circ} \mathrm{C}$, (c) Termogram 1 referencyjny odstẹp izoterm $1{ }^{\circ} \mathrm{C}$, (d) Rekonstrukcja z 656 próbek odstęp izoterm $1{ }^{\circ} \mathrm{C}$, (e) Rekonstrukcja z 6556 próbek odstęp izoterm $1{ }^{\circ} \mathrm{C}$, (f) Termogram 2 referencyjny odstęp izoterm $1^{\circ} \mathrm{C}$, (g) Rekonstrukcja z 656 próbek odstęp izoterm $10^{\circ} \mathrm{C}$, (h) Rekonstrukcja z 6556 próbek odstęp izoterm $10^{\circ} \mathrm{C}$, (i) Termogram 3 referencyjny odstęp izoterm $10^{\circ} \mathrm{C}$ 
where: $C$ - constant, $\mu$ - coherence between sampling matrix $\phi$ and signal base, $s$ - number of significant signal components (is lower than the all components signal), $n$ - number of all signal components. The coherence between the measurement base and the signal base is expressed by the highest correlation of random base vectors between the signal base and the measurement base (formula 9):

$$
\mu(\phi, \psi)=\sqrt{n} \cdot \max _{1 \leq k, j \leq n}\left|\left\langle\phi_{k}, \psi_{j}\right\rangle\right|
$$

where: $\phi_{\mathrm{s}}-$ components of the sampling matrix, $\psi$ - components signal base

Two implications arise from the above presented formulas $(8,9)$. The first one is that it is necessary to determine in an arbitrary way the threshold value that delimits the subset of significant components from the set of all values. Secondly, setting out coherence as such requires familiarity with signal components a priori. Consequently the method of delimiting the minimum number of samples according to formula 8 may not be applied easily in practice because it requires familiarity with the number of significant signal components and coherence between bases prior to execution of the measurement. In such an event it is only possible to assume arbitrarily the minimum number of samples, which would guarantee the correct image reconstruction with sufficient likelihood. The value of measurement error may be determined only once the real infrared radiation distribution is known, which is not guaranteed by this method.

Measurements using SPC with CS in far infrared ranges entail certain technological limitations in the spectrum aspect of the modulator structure. Another limitation, related to the method as such, is the significant uncertainty related to true reconstruction of temperature distribution. It is impossible to prove clearly the quality of enhancement of the thermograms reconstruction in the function of the number of used samples, because to a large extent this depends on the object of observation. By increasing the number of samples it is possible to minimise the error, yet this is also connected with extending the measurement time and gives rise to a higher computational cost.

\section{Conclusions}

Based on the implemented series of reconstructions for three different thermograms it has been found that increasing the number of samples approximates the correlation to one and increases the PSNR coefficient. The camera may be used to reconstruct a thermogram for observation purposes. At 1/100 measurements in relation to the total number of pixels the correlation remained higher than 0.85 . Measurements of electromagnetic radiation may also be carried out with the current reconstruction error. For the same number of samples, the difference of PSNR for two different images may exceed $30 \mathrm{~dB}$ and depends on the range of measured radiated power and image structure. For the analysed examples, at 1/100 measurements in relation to the total pixel number, in the worst case PSNR remained higher than $20 \mathrm{~dB}$. Apart from non-linear impact of the number of samples on the measurement error, a limitation in measurements of radiated power is constituted by the impact of the thermogram structure as such. Increasing the number of samples enhances mapping in a non-linear way, difficult to foresee. Larger ranges of measured temperatures cause impairment in PSNR and better contour mapping.

\section{References}

1. Więcek B., De Mey G., Termowizja w podczerwieni podstawy $i$ zastosowania. Wydawnictwo PAK, Warszawa 2011, ISBN 978-83-926319-7-2, 29-32, 103-130.

2. Chan W.L., Takhar D., Charan K., Kelly K.F., Baraniuk R.G., Mittelman D., Single-pixel terahertz camera speeds measurement, "Laser Focus World", No. 9, 2008, 73-75.

3. Edgar M.P., Gibson G.M., Bowman R.W., Sun B., Radwell N., Mitchel K.J., Welsh S.S., Padgett M.J., Simultaneous real-time visible and infrared video with single-pixel detectors. "Scientific Reports", 2015, 5,

DOI: $10.1038 /$ srep10669.

4. McLean D.F., Restoring Baird's Image (IEE History of Technology). IEE London 2000, ISBN 10:0852967950, 26-28.

5. Candes E., Romberg J., Tao T., Stable Signal Recovery from Incomplete and Inaccurate Measurements. "Communications on Pure and Applied Mathematics", Vol. 59, No. 8, 2006, 1207-1223, DOI: 10.1002/cpa.20124.

6. Duarte M.F., Davenport M.A., Takhar D., Laska J.N., Sun T., Kelly K.F., Baraniuk R.G., Single-Pixel Imaging via Compressive Sampling. "IEEE Signal Processing Magazine", Vol. 25, No. 2, 2008, 83-91, DOI: $10.1109 /$ MSP.2007.914730.

7. Wakin M.B., Laska J.N., Duarte M.F, Baron D., Sarvotham S., Takhar D., Kelly K.F., Baraniuk R.G., An Architecture for Compressive Imaging. International Conference on Image Processing, Atlanta, GA, USA, 8-11 Oct. 2006, DOI: $10.1109 /$ ICIP.2006.312577.

8. Jones-Bey H.A., Compressive sensing enables single-pixel digital camera, "Laser Focus World" Vol. 42, No. 11, 2006, 17-19.

9. Baraniuk R.G, Kelly K.F., Krishna S., Bridge R.F., Compressive sensing architecture advances infrared camera design. "Laser Focus World", No. 6, 2011, 31-34.

10. Heidari A., Saeedkia D., A 2D Camera Design with a Single-pixel Detector, 34th International Conference on Infrared, Millimeter, and Terahertz Waves. Busan, South Korea 21-25 Sept. 2009, DOI: 10.1109/ICIMW.2009.5324725.

11. Liu Hong-Chao, Zhang, S., Computational ghost imaging of hot objects in long-wave infrared range, Applied Physics Letters, Vol. 111, No. 3, 2017, DOI: 10.1063/1.4994662.

12. Kruse P.W., Skatrud D.D., Uncooled Infrared Imaging Arrays and Systems. Academic Press, San Diego 1997, eBook ISBN:9780080864440.

13. Kutyniok G., Theory and applications of compressed sensing, GAMM Mitteilungen, Vol. 36, No. 1, 2013, 79-101, DOI: 10.1002/gamm.201310005.

14. Takhar D., Laska J.N., Wakin M.B., Duarte M.F., Baron D., Sarvotham S., Kelly K.F., Baraniuk R.G., A New Compressive Imaging Camera Architecture using Optical-Domain Compression, Proceedings of SPIE - The International Society for Optical Engineering, 6065, 16-18 Jan. 2006, DOI: $10.1117 / 12.659602$.

15. Heng Bi, Xiao Zeng, Xin Tang, Shujia Qin, King Wai Chiu Lai, Compressive Video Recovery Using Block Match Multi-Frame Motion Estimation Based on Single Pixel Cameras, "Sensors", Vol. 16, No. 3, 2016,

DOI: $10.3390 / \mathrm{s} 16030318$.

16. Cevher V., Indyk P., Carin L., Baraniuk R.G., Sparse Signal Recovery and Acquisition with Graphical Models, "Signal Processing Magazine", Vol. 27, No. 6, 2010, 92-103, DOI: 10.1109/MSP.2010.938029.

17. Akshat D., Vadathya A.K., Mitra K., Compressive Image Recovery Using Recurrent Generative Model. IEEE Inter- 
national Conference on Image Processing (ICIP), Beijing, China, 17-20 Sept. 2017, DOI: 10.1109/ICIP.2017.8296572.

18. Mardani M., Gong E., Cheng J.Y., Pauly J., Xing L., Recurrent Generative Adversarial Neural Networks for Compressive Imaging. IEEE 7th International Workshop on Computational Advances in Multi-Sensor Adaptive Processing (CAMSAP), Curacao, Netherlands Antilles, 10-13 December 2017, DOI: 10.1109/CAMSAP.2017.8313209.

19. Bahmani S., Romberg J., Compressive Deconvolution in Random Mask Imaging. "IEEE Transactions on Computational Imaging", Vol. 1, No. 4, 2015, 236-246, DOI: $10.1109 /$ TCI.2015.2485941.

20. Arias-Castro E., Cande, E.J., Davenport M.A., On the fundamental limits of adaptive sensing, "IEEE Transactions on Information Theory", Vol. 59, No. 1, 2012, 472-481, DOI: $10.1109 /$ TIT.2012.2215837.

21. Huang G., Jiang H., Matthews K., Wilford P., Lensless Imaging By Compressive Sensing. IEEE International Conference on Image Processing, Melbourne, Australia, 15-18 Sept. 2013, DOI: 10.1109/ICIP.2013.6738433.
22. Gibson M.G., Sun B., Edgar M.P., Phillips D.B., Hempler N., Maker G.T., Malcolm G.P.A., Padgett M.J., Real-Time Imaging of Methane Gas Leaks Using a Single-Pixel Camera. Optics Express, Vol. 25, No. 4, 2017, 2998-3005, DOI: 10.1364/OE.25.002998.

23. Lee B., Introduction to \pm 12 Degree Orthogonal Digital Micromirror Devices (DMDs), Texas Instruments, 2018.

24. Don M.L., Fu C., Arce G.R., Compressive imaging via a rotating coded aperture, "Applied Optics", Vol. 56, No. 3, 2017, 142-153, DOI: 10.1364/AO.56.00B142.

25. Candes E., Romberg J., $l_{1}$-magic: Recovery of Sparse Signals via Convex Programming Caltech October 2005, https://statweb.stanford.edu/ candes/software/11magic/ downloads/11magic.pdf.

26. Candès E.J, Wakin M.B., An Introduction to Compressive Sampling. "IEEE Signal Processing Magazine", 2008, 25, 21-30, DOI: 10.1109/MSP.2007.914731.

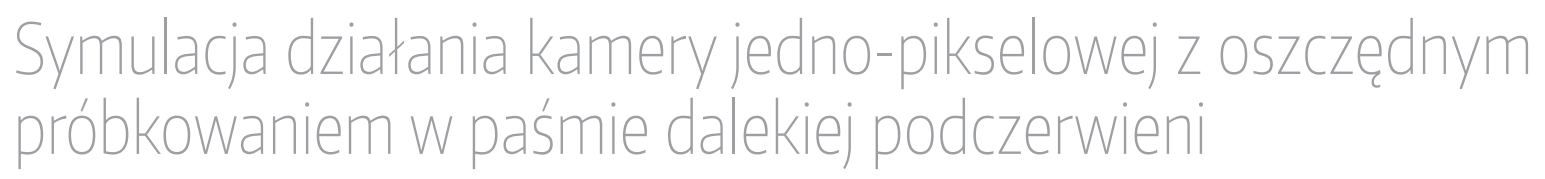

Streszczenie: Obrazowanie kamerą jednopikselową z użyciem CS (compressed sensing) jest nową i obiecującą technologią. Za pomocą CS można rekonstruować obrazy w różnych zakresach widmowych zależnie od czułości spektralnej użytego detektora. W pracy wykonano rekonstrukcję obrazu w zakresie LWIR (Long-Wave Infrared) na podstawie termogramu z zasymulowanej kamery jednopikselowej. Do rekonstrukcji użyto CS. Na podstawie analizy przypadków stwierdzono, że metodę CS można wykorzystać do budowania kamer obserwacyjnych jednopikselowych na podczerwień. Możliwe jest również zastosowanie tego rozwiązania w kamerach pomiarowych. Aby wykonać pomiar temperatury radiacyjnej należy dokonać kalibracji wyników uzyskanych na drodze rekonstrukcji CS. W badaniu zaproponowano sposób kalibracji kamery pomiarowej na podczerwień oraz zbadano wpływ liczby pomiarów na jakość rekonstrukcji. Zrekonstruowane termogramy porównano z referencyjnymi obrazami promieniowania podczerwonego. Stwierdzono, że redukcja błędu rekonstrukcji nie jest wprost proporcjonalna do zwiększanej liczby pobieranych próbek. Na podstawie analizy przypadków zaobserwowano, że poza liczbą pobieranych próbek, istotnym czynnikiem mającym wpływającym na wierność rekonstrukcji jest struktura samego obrazu. Dowiedziono, że szacowanie błędu dla zrekonstruowanych termogramów nie może być oparte tylko na liczbie wykonywanych pomiarów.

Słowa kluczowe: kamera jedno-pikselowa, oszczędne próbkowanie, pomiary w podczerwieni, kamera termowizyjna

\section{Anna Szajewska, PhD Eng.}

aszajewska@sgsp.edu.pl

ORCID: 0000-0001-8370-6807

Assistant Professor at Main School of Fire Service in Warsaw, Faculty of Fire Safety Engineering. Research interests: fire development research, computer image processing, infrared technology.

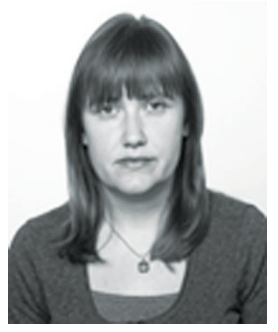

